University of Nebraska - Lincoln

DigitalCommons@University of Nebraska - Lincoln

\title{
Chlorpyrifos-Methyl Degradation and Biological Efficacy Toward Maize Weevils (Coleoptera: Curculionidae) on Corn Stored at Four Temperatures and Three Moisture Contents
}

\author{
Frank H. Arthur \\ USDA-ARS, frank.arthur@ars.usda.gov \\ James E. Throne \\ USDA-ARS, Manhattan, KS, james.throne@ars.usda.gov \\ Richard A. Simonaitis \\ USDA-ARS
}

Follow this and additional works at: https://digitalcommons.unl.edu/usdaarsfacpub

Arthur, Frank H.; Throne, James E.; and Simonaitis, Richard A., "Chlorpyrifos-Methyl Degradation and Biological Efficacy Toward Maize Weevils (Coleoptera: Curculionidae) on Corn Stored at Four Temperatures and Three Moisture Contents" (1991). Publications from USDA-ARS / UNL Faculty. 2002. https://digitalcommons.unl.edu/usdaarsfacpub/2002

This Article is brought to you for free and open access by the U.S. Department of Agriculture: Agricultural Research Service, Lincoln, Nebraska at DigitalCommons@University of Nebraska - Lincoln. It has been accepted for inclusion in Publications from USDA-ARS / UNL Faculty by an authorized administrator of DigitalCommons@University of Nebraska - Lincoln. 


\title{
Chlorpyrifos-Methyl Degradation and Biological Efficacy Toward Maize Weevils (Coleoptera: Curculionidae) on Corn Stored at Four Temperatures and Three Moisture Contents
}

\author{
FRANK H. ARTHUR, JAMES E. THRONE, AND RICHARD A. SIMONAITIS
}

Stored-Product Insects Research and Development

Laboratory, USDA-ARS, P.O. Box 22909, Savannah, Georgia 31403

\begin{abstract}
J. Econ. Entomol. 84(6): 1926-1932 (1991)
ABSTRACT Corn was treated with $6 \mathrm{ppm}$ chlorpyrifos-methyl and stored for $10 \mathrm{mo}$ at each of four temperatures $\left(15.0,22.5,30.0\right.$, and $\left.37.5^{\circ} \mathrm{C}\right)$ and three moisture contents (11.4, 12.4 , and $14.4 \%$ ). Every 2 mo, samples were removed from storage and analyzed for chlorpyrifos-methyl residue and infested with maize weevils, Sitophilus zeamais Motschulsky. Initial residues on the corn were $4.95 \pm 0.67 \mathrm{ppm}$. Of the residues that were lost, most were lost during the first $\mathbf{2}$ mo of storage. The loss rate increased as temperature and moisture content increased. No weevils survived on corn stored at 15.0 or $22.5^{\circ} \mathrm{C}$, except for $7.2 \%$ of the weevils that survived at month 10 on corn stored at $22.5^{\circ} \mathrm{C}$. Weevil survival increased as moisture content increased in corn stored at 30.0 and $37.5^{\circ} \mathrm{C}$. The threshold for weevil survival was $\approx 1.22 \mathrm{ppm}$ chlorpyrifos-methyl. Population growth, the percentage of insectdamaged kernels, and dockage weight were all correlated with insect survival.
\end{abstract}

KEY WORDS Insecta, Sitophilus zeamais, chlorpyrifos-methyl, insecticide degradation

INSECT PESTS in raw agricultural products are often controlled by applying a protectant insecticide to the commodity as it is loaded into storage. In the United States, the organophosphate insecticide chlorpyrifos-methyl (Reldan) is labelled at an application rate of $6 \mathrm{ppm}$ as a protectant for barley, oats, rice, sorghum, and wheat. Laboratory studies (LaHue 1976) and simulated field tests (LaHue 1977, Arthur et al. 1990) have also indicated that an application of 6-7 ppm chlorpyrifos-methyl would protect stored corn from insect damage during a typical storage season.

Organophosphate residue degradation in stored grain is primarily affected by storage temperature and moisture content of the stored commodity (Desmarchelier \& Bengston 1979). Numerous studies have shown that the rate of degradation of malathion, fenitrothion, and related organophosphates increases as temperature and moisture content increase (Snelson 1987). This continual degradation leads to a reduction in insecticide efficacy over storage time. If grain is stored under conditions that accelerate insecticide degradation, there may be an increased risk of insect infestation during storage.

There are no published data for chlorpyrifosmethyl degradation under controlled environmental conditions on corn stored over the full range of temperatures and moisture contents commonly en-

This article reports the results of research only, Mention of a proprietary product does not constitute an endorsement or a recommendation for its use by USDA. countered under field conditions. Such data are essential for predicting the residual effectiveness of chlorpyrifos-methyl. Data have been published concerning chlorpyrifos-methyl degradation on wheat stored at selected temperatures, but the effect of moisture content on degradation rate was not determined (LaHue 1974, Desmarchelier 1978). Also, efficacy data for insect pest species have not been integrated with residue studies. Samson et al. (1988) included chlorpyrifos-methyl in a study of the effects of corn with moisture contents $\geq 14 \%$ on the biological activity of freshly applied protectants. However, effects of temperature and storage time were not included, and some of the moisture contents used in the study may be considered excessive for field storage in the United States. Samson \& Parker (1989) evaluated the relative potency of chlorpyrifos-methyl and other protectants on corn, rice, and wheat stored at $30^{\circ} \mathrm{C}$ and $13.5,12.6$, and $13.5 \%$ moisture content, respectively.

Data integrating chlorpyrifos-methyl degradation on corn stored at different temperatures and moisture content with residual efficacy toward the primary insect pest species of stored corn in the United States, the maize weevil, Sitophilus zeamais (Motschulsky) (Coleoptera: Curculionidae), are necessary to develop management programs before chlorpyrifos-methyl is registered as a corn protectant. The three objectives of this study were: (1) to determine chlorpyrifos-methyl degradation rates on corn stored over a range of temperatures and moisture contents; (2) to determine biological activity of chlorpyrifos-methyl residues at each temperature and moisture content; and (3) to deter- 
mine subsequent insect damage resulting from initial exposure to chlorpyrifos-methyl residues.

\section{Materials and Methods}

Chlorpyrifos-methyl degradation was determined at $15.0,22.5,30.0$, and $37.5^{\circ} \mathrm{C}$ (in four cabinets) and at three humidities controlled by saturated aqueous solutions of $\mathrm{K}_{2} \mathrm{CO}_{3}, \mathrm{NaBr}$, and $\mathrm{NaCl}$ (Greenspan 1977), which were expected to produce equilibrium moisture contents of 11.0, 12.5, and $14.5 \%$, respectively. Approximately $720 \mathrm{ml}$ of each solution was poured into a plastic box ( 38.1 by 26.0 by $15.2 \mathrm{~cm}$ ), and a perforated false floor ( 35.6 by 25.4 by $1.3 \mathrm{~cm}$ ) was placed in the bottom of each box. Eight boxes were prepared for each of the three solutions (24 total).

'Pioneer 3320' corn obtained from a commercial storage facility was fumigated with phosphine to kill any incipient insect infestation and placed in cold storage $\left(4.4^{\circ} \mathrm{C}\right)$. The corn was removed from cold storage and allowed to warm for several days before being treated with $6 \mathrm{ppm}$ chlorpyrifosmethyl. Spray solutions were formulated in distilled water from a $4 \mathrm{E}(1.82 \mathrm{~kg} / 3.785$ liter, $4 \mathrm{lbs}$ [AI]/gal) source (Gustafson, Plano, Tex.), and the corn was sprayed at the rate of $18.9 \mathrm{ml}$ of formulated spray per $27.24 \mathrm{~kg}$ ( $1 \mathrm{bu})$. This rate is equivalent to the label rate of 18.92 liters $(5 \mathrm{gal})$ of formulated spray per $27,454 \mathrm{~kg}(1,000 \mathrm{bu})$. Chlorpyrifos-methyl was applied indoors using a modified insecticide delivery system equipped with a number 650067 Teejet nozzle (Spraying Systems, Wheaton, Ill.). Treatments were replicated four times, and after each bushel was sprayed, it was mixed by transferring the treated corn from one hopper-bottom cart to another three times. One bushel was treated with $18.9 \mathrm{ml}$ distilled water as a control and mixed in the same manner.

After each replicate bushel was treated, $350 \mathrm{~g}$ corn was placed in each of sixty 0.48 -liter jars. Each of forty-eight 0.48 -liter jars were filled with $350 \mathrm{~g}$ corn from the bushel sprayed with distilled water. All jars were sealed after they were filled. The jars were set in each of the four temperature cabinets as follows: five jars from replicate 1 , five jars from replicate 2 , and two jars of untreated corn were randomly placed in a solution box ( 12 jars in each box, three solution boxes). Five jars from replicate 3 , five jars from replicate 4 , and two jars of untreated corn were randomly placed in a second box. The boxes were randomly assigned to the shelves in the temperature cabinet (six boxes in each). To obtain data for month 0 (immediately after insecticide application), $350 \mathrm{~g}$ corn from each treated bushel and the untreated bushel were divided into two 0.24-liter jars containing $175 \mathrm{~g}$ each. One jar from each replicate was frozen at $-17.8^{\circ} \mathrm{C}$ for residue analysis. Fifty 1-2 wk old adult maize weevils (sex not determined) from pesticide-susceptible laboratory colonies were exposed in each of the other five jars. After $5 \mathrm{~d}$, the corn was sifted with a U.S. standard no. 8 sieve, then discarded. The remaining untreated corn was then rebagged and stored at $4.4^{\circ} \mathrm{C}$ until needed for subsequent bioassays.

The jars in the temperature cabinets were sampled as follows. At 2, 4, 6, 8, and $10 \mathrm{mo}$, one jar from each treated replicate was removed from the solution boxes ( 4 temperatures, 3 moisture contents, 4 replicates, for a total of 48 jars for each sample date). Corn moisture content was determined using a Burrows DMC-700 moisture computer (Seedboro Equipment Company, Chicago, Ill.), then $175 \mathrm{~g}$ were removed and placed in a 0.24 -liter jar, which was frozen at $-17.8^{\circ} \mathrm{C}$ for residue analysis. After 2 mo, moisture content of the untreated corn was monitored each week. The remaining $175 \mathrm{~g}$ were held in the original jar, and all 48 jars were placed in a controlled environment room $\left(28 \pm 1^{\circ} \mathrm{C}, 60\right.$ $\pm 2 \% \mathrm{RH}, 12: 12$ [L:D] photoperiod). In addition, 12 jars of $175 \mathrm{~g}$ untreated corn from the stored bushel were included as controls (one for each original storage temperature and moisture content). Fifty adult maize weevils from the pesticide susceptible colonies were exposed in each jar. After 5 $\mathrm{d}$, the corn was sifted and the number of survivors was recorded. Live weevils were returned to the jars, which were then returned to the control room. After $49 \mathrm{~d}$, the corn in each jar was resifted, and the number of live insects and the dockage weight was recorded. The corn was poured back into the jar, and a cylinder ( $11.43 \mathrm{~cm}$ long, $3.17 \mathrm{~cm}$ diameter) attached to a jar lid was used to remove a $37.7-\mathrm{ml}$ subsample, from which 100 kernels were removed and examined for insect damage. The treated corn was discarded after sampling at the respective intervals.

Chlorpyrifos-methyl residues were analyzed as previously described (Arthur et al. 1988). The 5-d weevil survival counts were corrected for control mortality by dividing treated survival by control survival and multiplying by 100 . Data were analyzed using the nonlinear regression procedure of the Statistical Analysis System (SAS Institute 1987) to fit asymptotic equations for residue degradation and weevil survival at each temperature and moisture content. The general linear model procedure was used to fit quadratic regression equations when asymptotic equations were not appropriate. Based on the results of a previous field study (Arthur et al. 1990), a threshold residue level for maize weevil survival was estimated as $1.22 \pm 0.06 \mathrm{ppm}$. A $5 \%$ survival level was also chosen as an arbitrary threshold to correspond with an $L D_{95}$, and the appropriate equations were solved for both thresholds. The linear correlation procedure was used to correlate residues and 5- and 49-d survival, 5-d with 49-d survival, and 5- and 49-d survival with percentage damaged kernels and dockage weight

All corn had equilibrated to the intended moisture content by the first sample date. Actual moisture content of the stored corn was determined by correlating oven dry weight of corn stored at dif- 
ferent temperatures with the readings given by the moisture computer. Mean readings were corrected with this method so that the actual moisture contents of corn held in the $11.0,12.5$, and $14.5 \%$ salt solutions were $11.4 \pm 0.1,12.4 \pm 0.2$, and $14.4 \pm$ $0.2 \%$, respectively. These new values were used in the statistical analyses.

\section{Results}

The intended chlorpyrifos-methyl application rate was $6 \mathrm{ppm}$, and actual deposition on the corn was $4.95 \pm 0.67(\bar{x} \pm \mathrm{SEM}) \mathrm{ppm}$. Residual degradation during storage increased as temperature increased, but as moisture content increased within each temperature, degradation increased only on corn stored at 30.0 and $37.5^{\circ} \mathrm{C}$ (Table 1). For all temperatures and moisture contents, most residue loss occurred during the first 2 mo of storage. Residue loss in corn stored at $14.4 \%$ moisture content and 15.0 and $22.5^{\circ} \mathrm{C}$ was 42.4 and $47.1 \%$, respectively, between 0 and 2 mo but was only 26.7 and $30.1 \%$, respectively, between 2 and 10 mo. Residue loss in corn stored at $37.5^{\circ} \mathrm{C}$ and $14.4 \%$ moisture content was $84.3 \%$ for months $0-2$ and $13.5 \%$ for months 2-10.

Chlorpyrifos-methyl degradation rates can be described by a series of asymptotic equations (Fig. 1). Model fitness increased as temperature increased, and $R^{2}$ values for $11.4,12.4$, and $14.4 \%$ moisture contents were as follows: $15.0^{\circ} \mathrm{C}$ : 0.68 , $0.63,0.77 ; 22.5^{\circ} \mathrm{C}: 0.82,0.80,0.82 ; 30.0^{\circ} \mathrm{C}: 0.90$, $0.91,0.92$; and $37.5^{\circ} \mathrm{C}: 0.91,0.91$, and 0.92 , respectively. The equations were used to predict the date when chlorpyrifos-methyl residues equaled $1.22 \mathrm{ppm}$, which was our estimated threshold for maize weevil survival. Residues on corn held at 15.0 and $22.5^{\circ} \mathrm{C}$ were always $>1.22 \mathrm{ppm}$. Setting $Y=1.22$, solving for $x$ in the equations for 11.4, 12.4 , and $14.4 \%$ moisture content at $30.0^{\circ} \mathrm{C}$, and multiplying by 30 to convert months to days show residues fell below the threshold residue level after $106 \pm 28,92 \pm 25$, and $61 \pm 12 \mathrm{~d}$, respectively.
At $37.5^{\circ} \mathrm{C}$ and $11.4,12.4$, and $14.4 \%$ moisture content, residues fell below the threshold after $64 \pm$ $22,51 \pm 23$, and $45 \pm 20 \mathrm{~d}$, respectively. Percentage maize weevil survival $5 \mathrm{~d}$ after introduction on corn removed from storage after 2-10 mo is shown in Table 2. No weevils survived on corn stored at 15.0 and $22.5^{\circ} \mathrm{C}$, except for month 10 for corn held at $22.5^{\circ} \mathrm{C}$ and $14.4 \%$ moisture content. Survival on that date was $7.2 \pm 5.2 \%$.

Percentage weevil survival in corn stored at $30.0^{\circ} \mathrm{C}$ increased as storage time and moisture content increased, and after 6 mo survival at $14.4 \%$ moisture content exceeded 96\%. After 2 mo, survival at $37.5^{\circ} \mathrm{C}$ and $14.4 \%$ moisture content was $55.6 \%$, but this was the only temperature-moisture regime where survival exceeded $1 \%$ after $2 \mathrm{mo}$. Percentage survival in corn held at $37.5^{\circ} \mathrm{C}$ and 11.4 , 12.4 , and $14.4 \%$ moisture content exceeded $96 \%$ after 8,6 , and 6 mo, respectively.

Asymptotic and quadratic regression equations relating percentage survival to storage time are plotted for the individual moisture contents for 30.0 and $37.5^{\circ} \mathrm{C}$ (Fig. 2). Survival for 11.4 and $12.4 \%$ moisture content at $30.0^{\circ} \mathrm{C}$ did not increase asymptotically, and data were analyzed by regression. Significance levels and $R^{2}$ for these moistures were 0.0001 and 0.59 , and 0.0001 and 0.94 , respectively. Survival was asymptotic for $30.0^{\circ} \mathrm{C}$ and $14.4 \%$ moisture content and for $37.5^{\circ} \mathrm{C}$ and $11.4,12.4$, and $14.4 \%$ moisture content. $R^{2}$ values were $0.89,0.95,0.98$, and 0.88 , respectively. At $30.0^{\circ} \mathrm{C}$, the $5 \%$ survival threshold occurred after $162.3,110.1$, and $66.6 \mathrm{~d}$ for the $11.0,12.4$, and $14.4 \%$ moisture contents. At $37.5^{\circ} \mathrm{C}, 5 \%$ survival occurred after $63.7,62.4$, and $29.5 \mathrm{~d}$.

Live weevil counts at day 49 in untreated controls averaged $116.5 \pm 4.0$. No live weevils were detected after $49 \mathrm{~d}$ in treated corn originally stored at 15.0 and $22.5^{\circ} \mathrm{C}$ at any of the bioassay intervals, with the exception of month 10 for $22.5^{\circ} \mathrm{C}$ and $14.4 \%$ moisture content (Table 3 ). The $49-\mathrm{d}$ count on that date was $9.5 \pm 0.5$. The number of weevils detected in the 49-d counts in corn originally stored

Table 1. Chlorpyrifos-methyl residues $\left(\bar{x} \pm\right.$ SEM) on corn stored at four temperatures and three moisture contents ${ }^{\natural}$

\begin{tabular}{ccccccc}
\hline \hline \multirow{2}{*}{ Temp, ${ }^{\circ} \mathrm{C}$} & $\begin{array}{c}\text { \% Moisture } \\
\text { content }\end{array}$ & \multicolumn{5}{c}{ Month } \\
\cline { 2 - 7 } & & 2 & 4 & 6 & 8 & 10 \\
\hline 15.0 & 11.4 & $2.70 \pm 0.13$ & $3.01 \pm 0.15$ & $2.65 \pm 0.21$ & $2.38 \pm 0.19$ & $2.14 \pm 0.20$ \\
& 12.4 & $3.58 \pm 0.33$ & $3.28 \pm 0.20$ & $2.78 \pm 0.20$ & $2.66 \pm 0.27$ & $2.37 \pm 0.33$ \\
& 14.4 & $2.85 \pm 0.23$ & $2.76 \pm 0.14$ & $2.11 \pm 0.05$ & $1.82 \pm 0.20$ & $1.53 \pm 0.20$ \\
22.5 & 11.4 & $2.80 \pm 0.16$ & $2.22 \pm 0.20$ & $1.92 \pm 0.08$ & $1.66 \pm 0.08$ & $1.48 \pm 0.16$ \\
& 12.4 & $3.35 \pm 0.13$ & $2.40 \pm 0.11$ & $2.26 \pm 0.06$ & $2.08 \pm 0.10$ & $1.80 \pm 0.21$ \\
& 14.4 & $2.62 \pm 0.33$ & $2.09 \pm 0.13$ & $2.01 \pm 0.00$ & $1.66 \pm 0.15$ & $1.13 \pm 0.02$ \\
30.0 & 11.4 & $1.91 \pm 0.08$ & $1.28 \pm 0.08$ & $0.80 \pm 0.09$ & $0.59 \pm 0.07$ & $0.47 \pm 0.05$ \\
& 12.4 & $1.70 \pm 0.10$ & $1.14 \pm 0.05$ & $0.74 \pm 0.07$ & $0.55 \pm 0.06$ & $0.40 \pm 0.06$ \\
37.5 & 14.4 & $1.65 \pm 0.12$ & $0.70 \pm 0.05$ & $0.52 \pm 0.03$ & $0.44 \pm 0.05$ & $0.26 \pm 0.02$ \\
& 11.4 & $1.29 \pm 0.04$ & $0.65 \pm 0.22$ & $0.50 \pm 0.05$ & $0.56 \pm 0.05$ & $0.25 \pm 0.02$ \\
& 12.4 & $0.94 \pm 0.05$ & $0.80 \pm 0.18$ & $0.40 \pm 0.04$ & $0.45 \pm 0.02$ & $0.18 \pm 0.03$ \\
& 14.4 & $0.78 \pm 0.03$ & $0.48 \pm 0.09$ & $0.26 \pm 0.02$ & $0.26 \pm 0.02$ & $0.11 \pm 0.02$ \\
\hline
\end{tabular}

a Theoretical application rate at month 0 was $6 \mathrm{ppm}$; actual deposition on the corn was $4.95 \pm 0.67 \mathrm{ppm}$ 

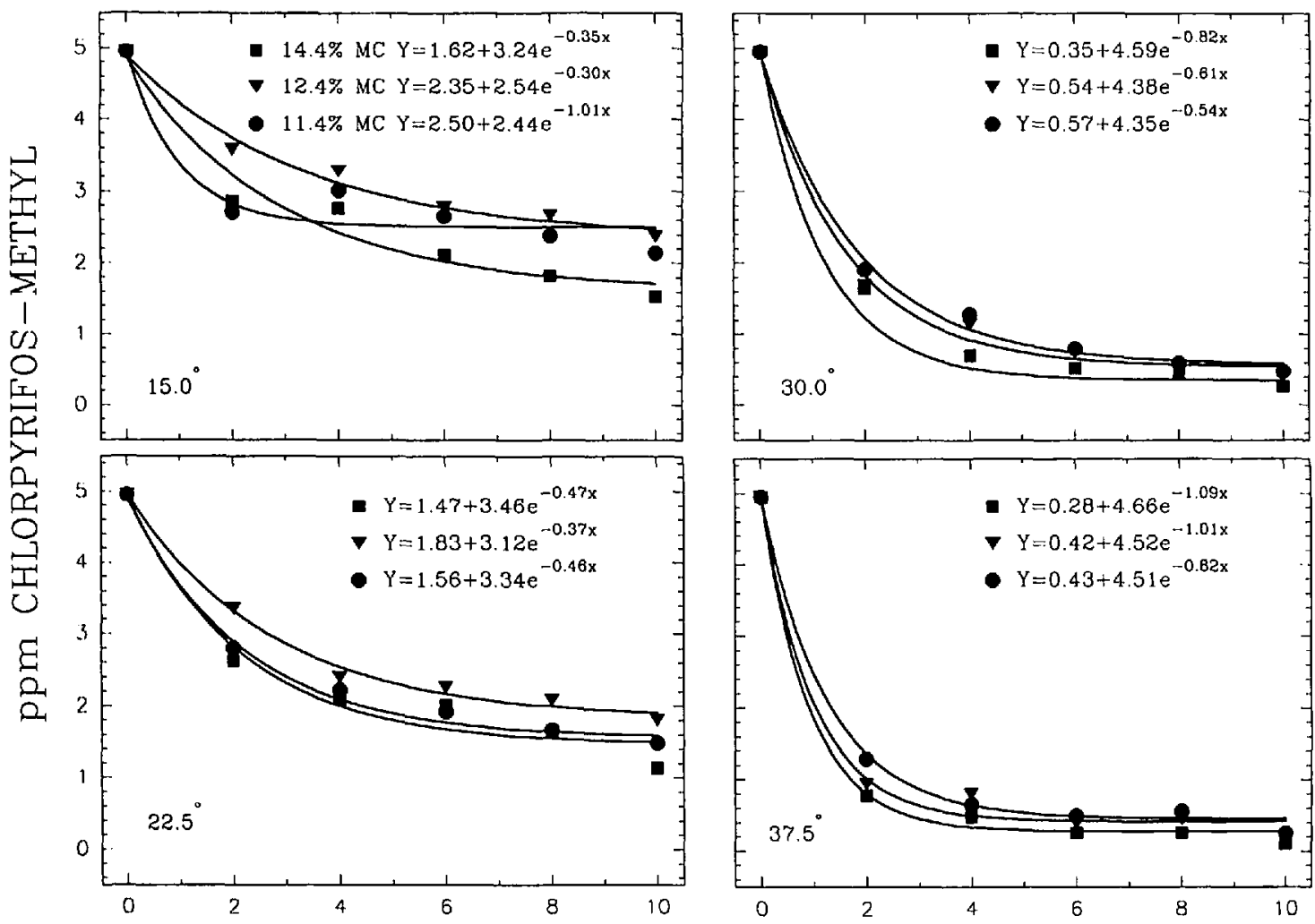

\section{STORAGE MONTH}

Fig 1. Asymptotic equations for chlorpyrifos-methyl degradation from an actual residual deposit of $4.95 \mathrm{ppm}$. Corn stored at four temperatures and three moisture contents. $Y, \mathrm{ppm}$ residue; $x$, storage month.

at $30.0^{\circ} \mathrm{C}$ increased over time and as moisture content increased. The number of weevils in the 49$\mathrm{d}$ counts in corn originally stored at $37.5^{\circ} \mathrm{C}$ and 11.4 and $12.4 \%$ moisture content also increased over time. However, the $49-\mathrm{d}$ counts in the $14.4 \%$ moisture content treatment were greatest at months 4 and 6 , which suggests that further population increases were limited by the amount of corn in the jar.

The 49-d dockage weights and the percentage of insect-damaged kernels in untreated controls av- eraged $1.9 \pm 0.06 \mathrm{~g}$ and $22.0 \pm 0.5 \%$, respectively. No dockage or insect-damaged kernels were found in treated corn originally stored at 15.0 and $22.5^{\circ} \mathrm{C}$, with the exception of corn examined at month 10 and stored at $22.5^{\circ} \mathrm{C}$ and 14.4 moisture content (Table 3). Dockage weight and insect-damaged kernels on that date were $0.2 \pm .1 \mathrm{~g}$ and $2.5 \pm$ $1.5 \%$, respectively. Within 30.0 and $37.5^{\circ} \mathrm{C}$, dockage weight and the percentage of insect-damaged kernels increased over time with increasing moisture content, except for $37.5^{\circ} \mathrm{C}$ and $14.4 \%$ moisture

Table 2. Percentage 5-d survival $(\bar{x} \pm$ SEM) of adult maize weevils introduced to corn treated with an intended application of $6 \mathrm{ppm}$ ehlorpyrifos-methyl ${ }^{a}$ and stored at four temperatures and three moisture contents for 2-10 month

\begin{tabular}{|c|c|c|c|c|c|c|}
\hline \multirow{2}{*}{ Temp, ${ }^{\circ} \mathrm{C}$} & \multirow{2}{*}{$\begin{array}{l}\% \text { Moisture } \\
\text { content }\end{array}$} & \multicolumn{5}{|c|}{ Storage month } \\
\hline & & 2 & 4 & 6 & 8 & 10 \\
\hline 30.0 & $\begin{array}{l}11.4 \\
12.4 \\
14.4\end{array}$ & $\begin{array}{l}0.0 \pm 0.0 \\
0.0 \pm 0.0 \\
0.0 \pm 0.0\end{array}$ & $\begin{array}{r}0.0 \pm 0.0 \\
0.0 \pm 0.0 \\
34.8 \pm 10.4\end{array}$ & $\begin{array}{r}8.3 \pm 3.7 \\
28.1 \pm 4.6 \\
96.7 \pm 1.3\end{array}$ & $\begin{array}{l}28.6 \pm 12.3 \\
57.7 \pm 6.0 \\
98.2 \pm 2.4\end{array}$ & $\begin{array}{l}57.1 \pm 16.7 \\
85.2 \pm 4.4 \\
97.2 \pm 1.0\end{array}$ \\
\hline 37.5 & $\begin{array}{l}11.4 \\
12.4 \\
14.4\end{array}$ & $\begin{array}{r}0.5 \pm 0.5 \\
0.5 \pm 0.5 \\
55.6 \pm 5.4\end{array}$ & $\begin{array}{l}57.7 \pm 7.0 \\
62.9 \pm 4.0 \\
89.4 \pm 3.9\end{array}$ & $\begin{array}{l}75.4 \pm 5.6 \\
96.7 \pm 2.0 \\
98.8 \pm 1.3\end{array}$ & $\begin{array}{r}96.7 \pm 1.3 \\
98.8 \pm 2.5 \\
101.3 \pm 1.8\end{array}$ & $\begin{array}{l}98.8 \pm 1.8 \\
99.3 \pm 2.3 \\
97.7 \pm 3.6\end{array}$ \\
\hline
\end{tabular}

a Introductions were made immediately after corn was removed from storage, at the rate of 50 weevils per $175 \mathrm{~g}$ corn. Actual deposition was $4.95 \mathrm{ppm}$. No survival at month 0 . Percentage survival on corn stored at 15.0 and $22.5^{\circ} \mathrm{C}$ was 0 on all sample dates except for month $10\left(22.5^{\circ} \mathrm{C}\right.$ and $14.5 \%$ moisture content $)$; survival for that date was $7.2 \pm 5.2 \%$. 


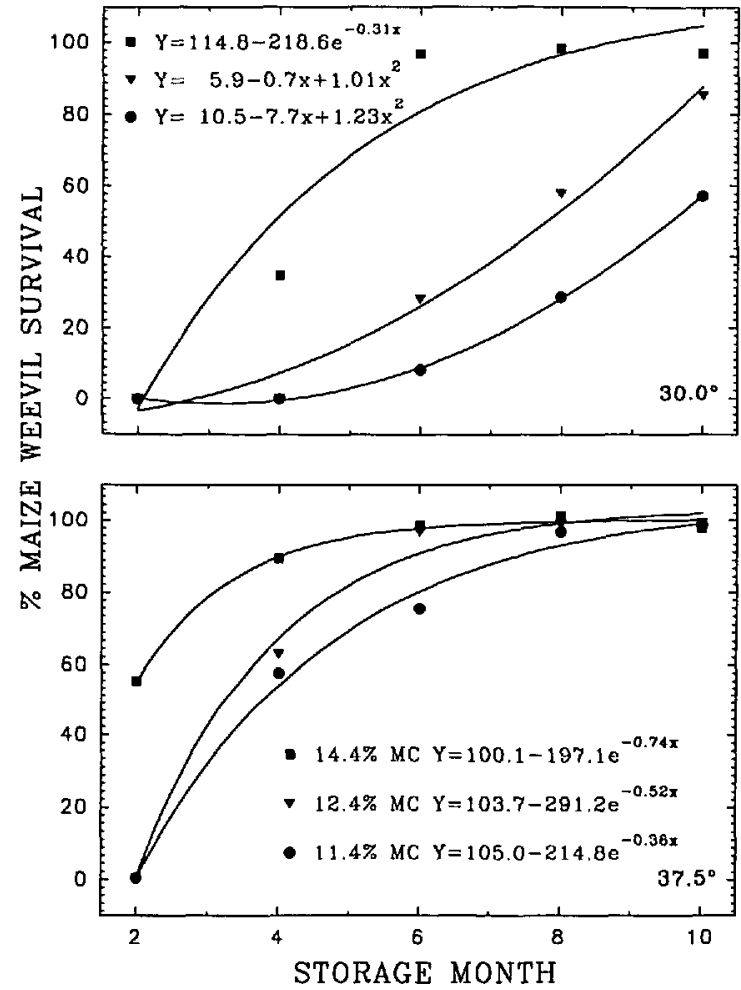

Fig 2. Asymptotic and quadratic regression equations for percentage survival from an introduction of 50 maize weevils to $175 \mathrm{~g}$ corn removed after $2,4,6,8$, and 10 mo of storage at 30.0 and $37.5^{\circ} \mathrm{C}$. $Y$, percentage survival; $x$, storage month. content. For this combination, dockage peaked at 6 and $10 \mathrm{mo}$ and percentage insect-damaged kernels peaked at $4 \mathrm{mo}$. The averages for the $250-\mathrm{ml}$ subsample weights ranged from $28.7 \pm 0.8$ to 32.8 $\pm 0.5,28.7 \pm 0.5$ to $32.9 \pm 0.7,26.2 \pm 0.5$ to 33.5 \pm 0.4 , and $25.3 \pm 1.1$ to $31.8 \pm 1.1 \mathrm{~g}$ for corn stored at $15.0,22.5,30.0$, and $37.5^{\circ} \mathrm{C}$, respectively. Weevil populations apparently did not affect the subsample weight, because no live weevils were ever detected in corn stored at 15.0 and $22.5^{\circ} \mathrm{C}$.

Temperatures of 15.0 and $22.5^{\circ} \mathrm{C}$ were eliminated from the correlation analysis because no live weevils were detected in the corn (Table 4). At each of the remaining six temperature-moisture combinations, chlorpyrifos-methyl residue levels were negatively correlated with maize weevil survival and with the subsequent $49-d$ counts. The $49-$ d counts were positively correlated with initial survival, and damage and dockage values were positively correlated with initial survival and with the 49-d weevil counts.

\section{Diseussion}

Initial chlorpyrifos-methyl residue deposits on the corn averaged $4.95 \pm 0.67 \mathrm{ppm}$, which was $82.5 \%$ of the calculated application rate of $6 \mathrm{ppm}$. Similar discrepancies between calculated dosages and actual residual deposition on raw agricultural products have been reported for a variety of residual protectants (Bengston et al. 1983a,b; Thomas et al. 1987). Residue loss in simulated and actual field applications is unavoidable for several reasons,

Table 3. Number of live maize weevils, dockage weight, and percentage insect-damaged kernels $(\bar{x} \pm$ SEM) in 175 $\mathrm{g}$ corn, $49 \mathrm{~d}$ after corn was removed from storage and infested at the rate of 50 adults per $175 \mathrm{~g}^{a}$

\begin{tabular}{|c|c|c|c|c|c|c|}
\hline \multirow{2}{*}{ Temp, ${ }^{\circ} \mathrm{C}$} & \multirow{2}{*}{$\begin{array}{l}\% \text { Moisture } \\
\text { content }\end{array}$} & \multicolumn{5}{|c|}{ Month corn removed from storage } \\
\hline & & 2 & 4 & 6 & 8 & 10 \\
\hline \multicolumn{7}{|c|}{ No. live weevils after $49 \mathrm{~d}$} \\
\hline 30.0 & $\begin{array}{l}11.4 \\
12.4 \\
14.4\end{array}$ & $\begin{array}{l}0.0 \pm 0.0 \\
0.0 \pm 0.0 \\
0.5 \pm 0.5\end{array}$ & $\begin{array}{r}0.0 \pm 0.0 \\
0.0 \pm 0.0 \\
35.5 \pm 6.5\end{array}$ & $\begin{array}{r}4.5 \pm 0.9 \\
12.7 \pm 0.6 \\
105.0 \pm 9.9\end{array}$ & $\begin{array}{r}2.5 \pm 1.2 \\
21.0 \pm 6.4 \\
127.5 \pm 19.7\end{array}$ & $\begin{array}{r}29.5 \pm 14.6 \\
60.0 \pm 15.7 \\
171.5 \pm 8.9\end{array}$ \\
\hline 37.5 & $\begin{array}{l}11.4 \\
12.4 \\
14.4\end{array}$ & $\begin{array}{r}0.0 \pm 0.0 \\
0.7 \pm 0.5 \\
24.2 \pm 4.4\end{array}$ & $\begin{array}{r}8.0 \pm 2.3 \\
28.0 \pm 4.2 \\
177.5 \pm 4.1\end{array}$ & $\begin{array}{r}22.2 \pm 7.1 \\
80.5 \pm 6.5 \\
176.0 \pm 28.1\end{array}$ & $\begin{array}{r}51.2 \pm 7.8 \\
84.0 \pm 7.4 \\
147.0 \pm 12.7\end{array}$ & $\begin{array}{r}95.0 \pm 7.2 \\
104.5 \pm 7.5 \\
154.0 \pm 7.9\end{array}$ \\
\hline \multicolumn{7}{|c|}{ Dockage wt, g } \\
\hline 30.0 & $\begin{array}{l}11.4 \\
12.4 \\
14.4\end{array}$ & $\begin{array}{l}0.0 \pm 0.0 \\
0.0 \pm 0.0 \\
0.0 \pm 0.0\end{array}$ & $\begin{array}{l}0.0 \pm 0.0 \\
0.1 \pm 0.0 \\
0.4 \pm 0.1\end{array}$ & $\begin{array}{l}0.1 \pm 0.0 \\
0.1 \pm 0.0 \\
1.3 \pm 0.1\end{array}$ & $\begin{array}{l}0.1 \pm 0.0 \\
0.3 \pm 0.0 \\
1.6 \pm 0.2\end{array}$ & $\begin{array}{l}0.5 \pm 0.2 \\
0.8 \pm 0.2 \\
2.6 \pm 0.1\end{array}$ \\
\hline 37.5 & $\begin{array}{l}11.4 \\
12.4 \\
14.4\end{array}$ & $\begin{array}{l}0.0 \pm 0.0 \\
0.0 \pm 0.0 \\
0.0 \pm 0.0\end{array}$ & $\begin{array}{l}0.2 \pm 0.0 \\
0.3 \pm 0.0 \\
2.0 \pm 0.2\end{array}$ & $\begin{array}{l}0.4 \pm 0.1 \\
1.5 \pm 0.1 \\
2.5 \pm 0.4\end{array}$ & $\begin{array}{l}0.9 \pm 0.2 \\
1.7 \pm 0.2 \\
2.2 \pm 0.2\end{array}$ & $\begin{array}{l}1.5 \pm 0.2 \\
1.7 \pm 0.2 \\
2.5 \pm 0.3\end{array}$ \\
\hline \multicolumn{7}{|c|}{$\%$ Insect-damaged kernels } \\
\hline 30.0 & $\begin{array}{l}11.4 \\
12.4 \\
14.4\end{array}$ & $\begin{array}{l}0.0 \pm 0.0 \\
0.0 \pm 0.0 \\
0.0 \pm 0.0\end{array}$ & $\begin{array}{l}1.2 \pm 0.5 \\
1.0 \pm 0.4 \\
8.5 \pm 0.6\end{array}$ & $\begin{array}{r}4.0 \pm 0.7 \\
9.2 \pm 1.1 \\
17.5 \pm 1.0\end{array}$ & $\begin{array}{r}4.5 \pm 0.3 \\
10.0 \pm 0.9 \\
18.0 \pm 2.4\end{array}$ & $\begin{array}{r}6.0 \pm 0.8 \\
9.0 \pm 0.7 \\
24.2 \pm 3.2\end{array}$ \\
\hline 37.5 & $\begin{array}{l}11.4 \\
12.4 \\
14.4\end{array}$ & $\begin{array}{l}0.0 \pm 0.0 \\
0.0 \pm 0.0 \\
0.0 \pm 0.0\end{array}$ & $\begin{array}{r}5.7 \pm 1.4 \\
12.5 \pm 1.2 \\
29.5 \pm 4.2\end{array}$ & $\begin{array}{r}8.2 \pm 2.4 \\
18.0 \pm 1.6 \\
23.0 \pm 2.2\end{array}$ & $\begin{array}{l}10.2 \pm 1.1 \\
17.0 \pm 1.2 \\
20.0 \pm 3.4\end{array}$ & $\begin{array}{l}12.5 \pm 1.5 \\
18.2 \pm 1.6 \\
25.2 \pm 3.0\end{array}$ \\
\hline
\end{tabular}

a Number of live weevils found in corn originally stored at 15.0 and $22.5^{\circ} \mathrm{C}$ was 0 on all sample dates except for month 10 at $22.5^{\circ} \mathrm{C}$ and $14.5 \%$ moisture content. Number of live weevils, dockage weight, and percentage insect-damaged kernels on that date were 9.5 $\pm 0.5,0.2 \pm 0.1 \mathrm{~g}$, and $2.5 \pm 1.5 \%$, respectively. 
Table 4. Correlation coefficients for residue versus survival and 49-d live weevil counts, survival versus 49-d counts, and survival and 49-d counts versus dockage weight and percentage insect-damaged kernels for each eorn moisture content at 30.0 and $37.5^{\circ} \mathrm{C}$

\begin{tabular}{|c|c|c|c|c|c|c|}
\hline & \multicolumn{2}{|c|}{$11.4 \%$} & \multicolumn{2}{|c|}{$12.4 \%$} & \multicolumn{2}{|c|}{$14.4 \%$} \\
\hline & Day 5 & Day 49 & Day 5 & Day 49 & Day 5 & Day 49 \\
\hline \multicolumn{7}{|c|}{$30^{\circ} \mathrm{C}$} \\
\hline Residue & -0.68 & -0.45 & -0.86 & -0.70 & -0.88 & -0.81 \\
\hline Day 5 & - & 0.83 & - & 0.86 & - & 0.88 \\
\hline Damage & 0.75 & 0.64 & 0.80 & 0.62 & 0.87 & 0.92 \\
\hline Dockage & 0.83 & 0.99 & 0.81 & 0.98 & 0.86 & 0.98 \\
\hline \multicolumn{7}{|c|}{$37.5^{\circ} \mathrm{C}$} \\
\hline Hesidue & -0.83 & -0.66 & -0.77 & -0.87 & -0.85 & -0.69 \\
\hline Survival & - & 0.77 & - & 0.90 & - & 0.82 \\
\hline Damage & 0.90 & 0.82 & 0.94 & 0.89 & 0.72 & 0.88 \\
\hline Dockage & 0.78 & 0.98 & 0.85 & 0.95 & 0.84 & 0.94 \\
\hline
\end{tabular}

such as spray drift or transfer of residue from the treated commodity to conveying and mixing equipment. Therefore, the beginning point for residue degradation studies is not the intended application rate but an actual deposition that is at least 10-20\% less.

Even when storage temperatures were low, chlorpyrifos-methyl degradation on stored corn occurred more rapidly during the first 2 mo than at any other time during storage. As corn temperature and moisture content increased, chlorpyrifosmethyl degradation increased. This has important implications for field control, especially if corn is harvested during unusually warm and humid conditions, treated with organophosphate protectants such as chlorpyrifos-methyl, and immediately loaded into storages with no environmental controls. This initial degradation could cause residue deposits to decline below levels that would prevent insect infestations during the final months of storage. Excessive corn moisture contents may also reduce the biological effectiveness of chlorpyrifosmethyl and other organophosphate protectants (Samson et al. 1987, 1988).

The chlorpyrifos-methyl degradation rates on corn greatly exceeded those reported for grain by Desmarchelier \& Bengston (1979). In their study, chlorpyrifos-methyl residues on grain stored at $30.0^{\circ} \mathrm{C}$ and $50 \%$ RH $(\approx 11.9 \%$ moisture content) had a half-life of $19 \mathrm{wk}$, whereas the half-life for residues on corn stored at $30.0^{\circ} \mathrm{C}$ and $11.4,12.4$, and $14.4 \%$ in our test were $\approx 6.1,5.4$, and $3.8 \mathrm{wk}$, respectively. These discrepancies could be an indication that protectant degradation rates differ among stored commodities, particularly between small grains and corn.

The effective residue threshold level of $1.22 \mathrm{ppm}$ chlorpyrifos-methyl appeared to be a valid estimate for maize weevil survival. This estimate was based on the results of a previous test in which several stored product beetle species, including maize weevils, did not survive exposure to corn treated with chlorpyrifos-methyl until aged residues fell below $1.22 \mathrm{ppm}$ (Arthur et al. 1990). In the current test, maize weevil survival was always
0 when residues were $>1.65 \mathrm{ppm}$ and was always $>0$ when residues were $\leq 0.94 \mathrm{ppm}$. There were six values between these points; 1.13, 1.14, 1.28, $1.29,1.49$, and $1.53 \mathrm{ppm}$; weevil survival was 7.2 $\pm 5.2 \%$ and $0.5 \pm 0.5 \%$ at 1.13 and $1.29 \mathrm{ppm}$ respectively, and 0 at the other four. The risk of maize weevil infestation increases because of the accelerated decrease of chlorpyrifos-methyl residues at high temperatures and moisture contents, which reduces the length of residual control given by the protectant. The length of residual control for corn stored at $30.0^{\circ} \mathrm{C}$ and $11.4 \%$ moisture content, as determined by $5 \%$ survival, was $162.3 \mathrm{~d}$ $(\approx 5.4 \mathrm{mo}$ ), but chlorpyrifos-methyl residues on corn stored at $<22.5^{\circ} \mathrm{C}$ and $14.4 \%$ moisture gave complete control for $10 \mathrm{mo}$. This would indicate that corn stored at temperatures $>22.5^{\circ} \mathrm{C}$ becomes increasingly vulnerable to maize weevil infestation during a typical 10-mo storage period.

The secondary parameters evaluated in our study (the 49-d live weevil counts, dockage weight, and the percentage of insect-damaged kernels) were determined after the jars containing the treated corn were removed from the humidity boxes inside the four constant temperature cabinets and held under uniform conditions for $49 \mathrm{~d}$. This was necessary because two of the temperatures used in this study, 15.0 and $22.5^{\circ} \mathrm{C}$, were below the optimum temperature range of $26-31^{\circ} \mathrm{C}$ for Sitophilus spp. population growth and development (Howe 1965). In our previous test (Arthur et al. 1990), beetle populations did not develop in untreated corn stored under simulated field conditions until ambient temperatures consistently were $>22.5^{\circ} \mathrm{C}$. In the current test, because all corn was held at the same conditions after insects were introduced, any differences in weevil progeny production or corn damage parameters were related to the amount of chlorpyrifos-methyl residue on the corn. Statistical analyses showed that the $49-\mathrm{d}$ counts and the damage parameters were correlated with initial survival, which in turn was correlated with chlorpyrifos-methyl residues.

In conclusion, residual degradation of chlorpyrifos-methyl on stored corn increases dramatically 
when storage temperature and corn moisture content increase, and degradation rates are considerably greater than those previously reported for small grains. The results emphasize the necessity of developing and properly using aeration systems which would lower corn storage temperatures and moisture contents. The lower temperatures would slow the rate of chlorpyrifos-methyl degradation, thereby maintaining residue levels that would kill maize weevils immigrating into stored corn. In addition, aeration may reduce storage temperatures and moisture contents below the optimum level required for insect population growth and development.

\section{Acknowledgment}

The authors thank J. E. O'Bryan for his excellent technical assistance; and Gustafson, Inc., for providing the chlorpyrifos-methyl used in this study. We thank V. Chew for assistance with the statistical analysis. We also thank J. E. Baker, G. W. Cuperus, J. G. Leesch, J. D. Sedlacek, and $\mathrm{L}$. Smith for reviewing this manuscript.

\section{References Cited}

Arthur, F. H., L. M. Redlinger \& R. A. Simonaitis. 1988. Chlorpyrifos-methyl as a protectant of farmers stock peanuts. Peanut Sci. 15: 15-18.

Arthur, F. H., J. E. Throne, R. A. Simonaitis \& J. M. Zehner. 1990. Evaluation of chlorpyrifos-methyl and chlorpyrifos-methyl + methoprene as protectants of stored corn: small bin tests. J. Econ. Entomol. 83: 1114-1121.

Bengston, M., R.A.H. Davies, J. M. Desmarchelier, R. Henning, W. Murray, B. W. Simpson, J. T. Snelson, R. Sticka \& B. E. Wallbank. 1983a. Organophosphorothioates and synergised synthetic pyrethroids as grain protectants on bulk wheat. Pestic. Sci. 14: 373-384.

Bengston, M., L. M. Cooper, R.A.H. Davies, J. M. Desmarchelier, R. H. Hart \& M. P. Phillips. 1983 b. Grain protectants for the control of malathion-resistant insects in stored sorghum. Pestic. Sci. 14: 385398.
Desmarchelier, J. M. 1978. Mathematical examination of availability to insects of aged insecticide deposits on wheat. J. Stored Prod. Res. 14: 213-222.

Desmarchelier, J. M. \& M. Bengston. 1979. The residual behavior of chemicals on stored grain, pp. 138151. In Proceedings of the 2nd International Working Conference on Stored-Product Entomology, Ibadan, Nigeria.

Greenspan, L. 1977. Humidity fixed points of binary saturated aqueous solutions. J. Res. U.S. Nat. Bur. Stand. 81A: 89-96.

Howe, R. W. 1965. A summary of estimates of optimal and minimal conditions for population increase of some stored products insects. J. Stored Prod. Res. 1: 177-184.

LaHue, D. W. 1974. Pesticide residues of potential protectants of grain, pp. 635-638. In Proceedings of the 1st International Working Conference on StoredProduct Entomology, Savannah, Ga.

1976. Grain protectants for seed corn. J. Econ. Entomol. 69: 652-654.

1977. Grain protectants for seed corn: field test. J. Econ. Entomol. 70: 720-722.

Samson, P. R. \& R. J. Parker. 1989. Relative potency of grain protectants on maize, paddy rice, and wheat. J. Stored Prod. Res. 25: 31-38.

Samson, P. R., M. Bengston, R. J. Parker \& J. A. Keating. 1987. The effect of grain moisture on the biological activity of fenitrothion residues on maize in storage. Pestic. Sci. 19: 135-144.

Samson, P. R., R. J. Parker \& A. L. Jones. 1988. Comparative effect of grain moisture on the biological activity of protectants on stored corn. J. Econ. Entomol. 81: 949-954.

SAS Institute. 1987. SAS/STAT guide for personal computers, version 6 ed. SAS Institute, Cary, N.C.

Snelson, J. T. 1987. Grain protectants. Australian Centre for International Agricultural Research Monograph No. 3.

Thomas, K. P., D. B. Pinniger \& D. R. Wilkin. 1987. An assessment of chlorpyrifos-methyl, etrimfos, fenitrothion and pirimiphos-methyl as grain protectants. Pestic. Sci. 21: 57-72.

Received for publication 30 July 1990; accepted 7 June 1991. 